\title{
MATHEMATICAL MODELING APPLIED TO THE GROWTH OF TILAPIA IN NET CAGES IN THE SUB MIDDLE OF THE SÃO FRANCISCO RIVER
}

\author{
JOSÉ DE A. DE SOUSA JÚNIOR ${ }^{1}$, MARLON DA S. GARRIDO ${ }^{2}$, PAULO G. S. DE \\ CARVALHO ${ }^{3}$, LUCIANO G. DA ROCHA ${ }^{4}$, DANIELA F. B. CAMPECHE ${ }^{5}$
}

\begin{abstract}
This study aimed to apply mathematical models to the growth of Nile tilapia (Oreochromis niloticus) reared in net cages in the lower São Francisco basin and choose the model(s) that best represents the conditions of rearing for the region. Nonlinear models of Brody, Bertalanffy, Logistic, Gompertz, and Richards were tested. The models were adjusted to the series of weight for age according to the methods of Gauss, Newton, Gradiente and Marquardt. It was used the procedure "NLIN" of the System SAS ${ }^{\circledR}$ (2003) to obtain estimates of the parameters from the available data. The best adjustment of the data were performed by the Bertalanffy, Gompertz and Logistic models which are equivalent to explain the growth of the animals up to 270 days of rearing. From the commercial point of view, it is recommended that commercialization of tilapia from at least $600 \mathrm{~g}$, which is estimated in the Bertalanffy, Gompertz and Logistic models for creating over 183, 181 and 184 days, and up to $1 \mathrm{Kg}$ of mass, it is suggested the suspension of the rearing up to 244,244 and 243 days, respectively.
\end{abstract}

KEYWORDS: economy, equations, Oreochromis niloticus.

\section{MODELAGEM MATEMÁTICA APLICADA AO CRESCIMENTO DE TILÁPIAS EM TANQUES-REDE NO SUBMÉDIO DO SÃO FRANCISCO}

RESUMO: Este estudo teve como objetivo aplicar modelos matemáticos ao crescimento de tilápias-do-nilo (Oreochromis niloticus) criadas em tanques-rede no Submédio do São Francisco e escolher o(s) modelo(s) que melhor representa $(\mathrm{m})$ as condições de criação para a região. Foram utilizados os modelos não lineares de Brody, Bertalanffy, Logístico, Gompertz e Richards. Os modelos foram ajustados às séries de peso por idade, de acordo com os métodos iterativos de Gauss, Newton, Gradiente e Marquardt. Foi utilizado o procedimento "NLIN" do Sistema SAS ${ }^{\circledR}$ (2003) para a obtenção das estimativas dos parâmetros a partir dos dados disponíveis. O melhor ajuste dos dados foi realizado pelos modelos de Bertalanffy, Gompertz e Logístico, que são equivalentes para explicar o crescimento dos animais até 270 dias de criação. Sob o ponto de vista comercial, recomenda-se a comercialização das tilápias com, pelo menos, $600 \mathrm{~g}$, que é estimado nos modelos de Bertalanffy, Gompertz e Logístico para criações superiores a 183; 181 e 184 dias, e para massa de até $1 \mathrm{~kg}$, sugere-se a suspenção da criação em até 244; 244 e 243 dias, respectivamente.

PALAVRAS-CHAVE: economia, equações, Oreochromis niloticus.

\section{INTRODUCTION}

The rearing of Nile tilapia, Oreochromis niloticus, for commercial purposes is developed practically, in all states of Brazil, in rearing usually made in net cages, and the products are intended for different market niches (KUBITZA , 2007). The production of this species, according to the

\footnotetext{
${ }^{1}$ Zootecnista, Mestre em Eng. Agrícola pela UNIVASF/Juazeiro - BA, Fone: (84) 3316-7134, alencarjunior@ zootecnista.com.br;

${ }^{2}$ Eng. Agrônomo, Prof. Adjunto da Pós graduação de Eng. Agrícola, Colegiado de Engenharia Agrícola, UNIVASF/Juazeiro - BA, garridoms.univasf@gmail.com;

${ }^{3}$ Físico, Prof. Adjunto da Pós graduação de Engenharia Agrícola, Colegiado de Engenharia Agrícola, UNIVASF/Juazeiro - BA, paulo.carvalho@univasf.edu.br;

${ }^{4}$ Eng. de Pesca da CODEVASF, Superintendência Regional de Juazeiro - BA, alenkjr@hotmail.com;

${ }^{5}$ Biológa, Mestre em Ciência Animal, Pesquisadora da EMBRAPA Semiarido, Petrolina - PE, dabacconi@ hotmail.com.

Recebido pelo Conselho Editorial em: 15-1-2013

Aprovado pelo Conselho Editorial em: 2-5-2014
}

Eng. Agríc., Jaboticabal, v.34, n.5, p. 1001-1011, set./out. 2014 
MPA (2010), represents 39\% of the Brazilian production of freshwater fish culture, being the most important farmed fish.

For a successful rearing, it is important to monitor the animal growth, because it is an important ecological parameter that can serve as an indicator of life conditions of these organisms: those living in better environmental conditions will grow faster than those that are living in nonideal or degraded environments (SIANGAS et al., 2012).

In this context, the São Francisco valley is characterized by bringing together the ideal conditions for the development of fish farming: there is plenty of water, both in quantity and quality and also presents warm weather with little temperature variation through the whole year (CODEVASF, 2010).

The net cages are enclosed structures of screen or net, that holds the fish and enable full water exchange in the form of continuous flow, facilitating the visualization of fish and simplifies the handling of animals. The development of farming in net cages must be managed with planning, technical and legal knowledge, aiming the sustainability of the business.

Growth data adjustment based on weight-age functions that describes the whole period of animal life becomes more informative: it allows to obtain accurate information about the mass gain of the animals (TEXEIRA et al, 2012.). A lot of authors studies the development of the fish body. According to VANDER et al. (2007), to study the growth by adjusting a function that describes the entire life of the animal becomes more informative: it condenses the information from a series of data in a small set of biologically interpretable parameters.

In this conception, the purpose of this study was to apply mathematical growth models of Nile tilapia (Oreochromis niloticus) created in net cages in the Sub middle of the São Francisco river and choose the model/models that best represents the conditions of rearing for this region.

\section{MATERIALS AND METHODS}

Data collection was performed in CODEVASF/ Embrapa Semi-Arid - CPATSA and covers the production of Nile tilapia in net cages of a commercial property in a complete cycle of rearing, in Juazeiro, BA. The region climate is type Bswh, according to Köeppen classification.

In total, there were 270 days, 9 biometrics, with 83 fish weighed in each measurement, resulting in a total of 747 fish. The rearing period occurred on September 13th of 2010 to May 9th of 2011. Measurements were performed monthly. The fingerlings used had an average of initial weight $10.53 \pm 2.17 \mathrm{~g}$.

Water analyzes for monitoring physico-chemical parameters were performed. For fish feeding, commercial extruded feed was offered, initially to $44 \%$ crude protein (CP), and according to fish evolution, CP content had a decrease to $36 \%$ and later to $32 \%$. The amount of feed was calculated, for each enclosure, based on biomass: proportion of $4 \%$ and $3 \%$.

Five non-linear models were used to choose the one that best described the fish growth curve. They are: Brody (Brody, 1945), Bertalanffy (BERTALANFFY, 1957), Gompertz (LAIRD, 1965), Logistics (Nelder, 1961), Richards (RICHARDS, 1959), which have their mathematical representation according to the equations: Eq.1, Eq.2, Eq.3, Eq.4 and Eq.5 respectively.

$$
\begin{aligned}
& Y=A\left(1-B e^{-k t}\right)+\varepsilon_{;} \\
& Y=A\left(1-B e^{-k t}\right)^{3}+\varepsilon_{;} \\
& Y=A e^{-B e^{-k t}}+\varepsilon_{;} \\
& Y=A\left(1+B e^{-k t}\right)^{-1}+\varepsilon_{;} \\
& Y=A\left(1-B e^{-k t}\right)^{M}+\varepsilon_{;}
\end{aligned}
$$


where,

$\mathrm{Y}=$ the fish weight to a certain age $(\mathrm{t})$;

$\mathrm{A}=$ the asymptotic value of $\mathrm{Y}$ (average weight at maturity);

$\mathrm{B}=$ the integration constant related to the initial weights (animal maturity degree at birth);

$\mathrm{k}=$ the variation rate of the exponential function (speed that the animal is approaching to the adult body weight), and

$\mathrm{M}=$ the parameter that shapes the curve, which corresponds to 1 to the Brody model, 3 to the Bertalanffy, -1 for the Logistic, tends to $\infty$ for the Gompertz and is variable to the Richards.

In nonlinear models, it is not executable solving the equations system formed directly, since that the system resolution depends directly of the specific parameters to be estimated. You must use the iterative process for the acquisition of estimated parameters. Iterative methods are those that define an infinite sequence of operations, determining a sequence of approximations, whose limit is the exact solution of the system (BARD, 1974).

The iterative Newton method (MACLEOD, 1984), allows the approximation of the solution of a nonlinear equation, starting from a initial value $x_{1}$, generating a sequence of values $x_{i}(i=1,2, \ldots)$. So, up to when the desired approximation is achieved. The line that passes through $\left(x_{1}, y_{1}=f\left(x_{1}\right)\right)$ is given by: $y=f^{\prime}\left(x_{1}\right)\left(x-x_{1}\right)+f\left(x_{1}\right)$, that intersects the axis of $x$ on the abscissa point $x_{2}=x_{1}-\frac{f\left(x_{1}\right)}{f^{\prime}\left(x_{1}\right)}$. This value allows to generate, by the same method, a new value $x_{3}=x_{2}-\frac{f\left(x_{2}\right)}{f^{s}\left(x_{2}\right)}$ from the abscissa of the intersection point of the tangent to $f(x)$ on the point $\left(x_{2} y_{2}=f\left(x_{2}\right)\right)$ and so on. It is a method based on the calculation of the function derivative $f(x)$.

The iterative gradient method requires the calculation of first and second derivatives, i.e. partial ones. The numerical minimization procedure is finished according to a convergence criterion. The gradient method or the Maximum Descent uses the negative of gradient of the objective function as a search direction. This method relies on the fact that, at a certain point, the gradient opposite direction of the objective function is the direction of the maximum decrease of the objective function (BARD, 1970).

The iterative Gauss method is a method used for solving problems of nonlinear least squares. It can be seen as a modification of the Newton method to find the minimum of a function (HARTLEY, 1961). Unlikely the Newton method, the Gauss algorithm can be used only for minimizing a sum of squared values of the function, but has the advantage that the second derivatives, which can be hard to calculate, are not necessary (JENNRICH. 1969).

The iterative Marquardt method in practice, has global convergence characteristics: converges to the local minimum from any approximate value, being the limit of the step size done through the use of trust region (MARQUARDT, 1963). Although it is very optimized, this procedure depends on several factors that may influence its convergence or not, such as: data number, the type of equation to be adjusted and the initial estimates of the coefficients (WU, 2000).

The NLIN procedure estimates the parameters of nonlinear models by the method of the least squares. The non-linear models are more difficult to estimate parameters than the linear models (RATKWOSKY, 1990). The regression expression must be written, to declare the parameters, providing initial values. Some models are difficult to adjust, and there is no guarantee that the procedure can successfully adjust the model (JENNRICH \& MOORE, 1975).

To start the estimation of the mathematical parameters models, the NLIN procedure first examines the specifications of the parameters initial values already inserted in the model. Thereafter 
the NLIN evaluates the sum of the residual squares for each combination of parameter values to determine the set of parameter values that produce the smallest sum of the residual squares.

The models adjustments to the data were made by the procedure "NLIN" SAS 2003 and iterative methods of Gauss, Newton, Gradient and Marquardt. In these methods, the iterative process converges in the $\mathrm{j}$-th iteration when $\left(\mathrm{SRS}_{\mathrm{j}-1}-\mathrm{RS}_{\mathrm{j}}\right) /\left(\mathrm{SRSj}+10^{-6}\right)<10^{-8}$. The $10^{-8}$ value is the value that determines the convergence of the model. The convergence of a mathematical model ensures that the sum of the residual squares (SRS) of its parameters is minimal, tending to zero.

The best model selection, the one developed aiming the selection of an optimal solution (BAIO et al, 2013) was performed on the basis of simple indicators, considering: the data convergence, the determination coefficient $\left(\mathrm{R}^{2}\right)$ and the sum of residual squares (SRS). In this study, weight and mass are considered synonymous.

The table below shows an application of the NLIN procedure of SAS, together with the iteration Gauss method, in the function setting of von Bertalanffy to the tilapia weight in the SAS program.

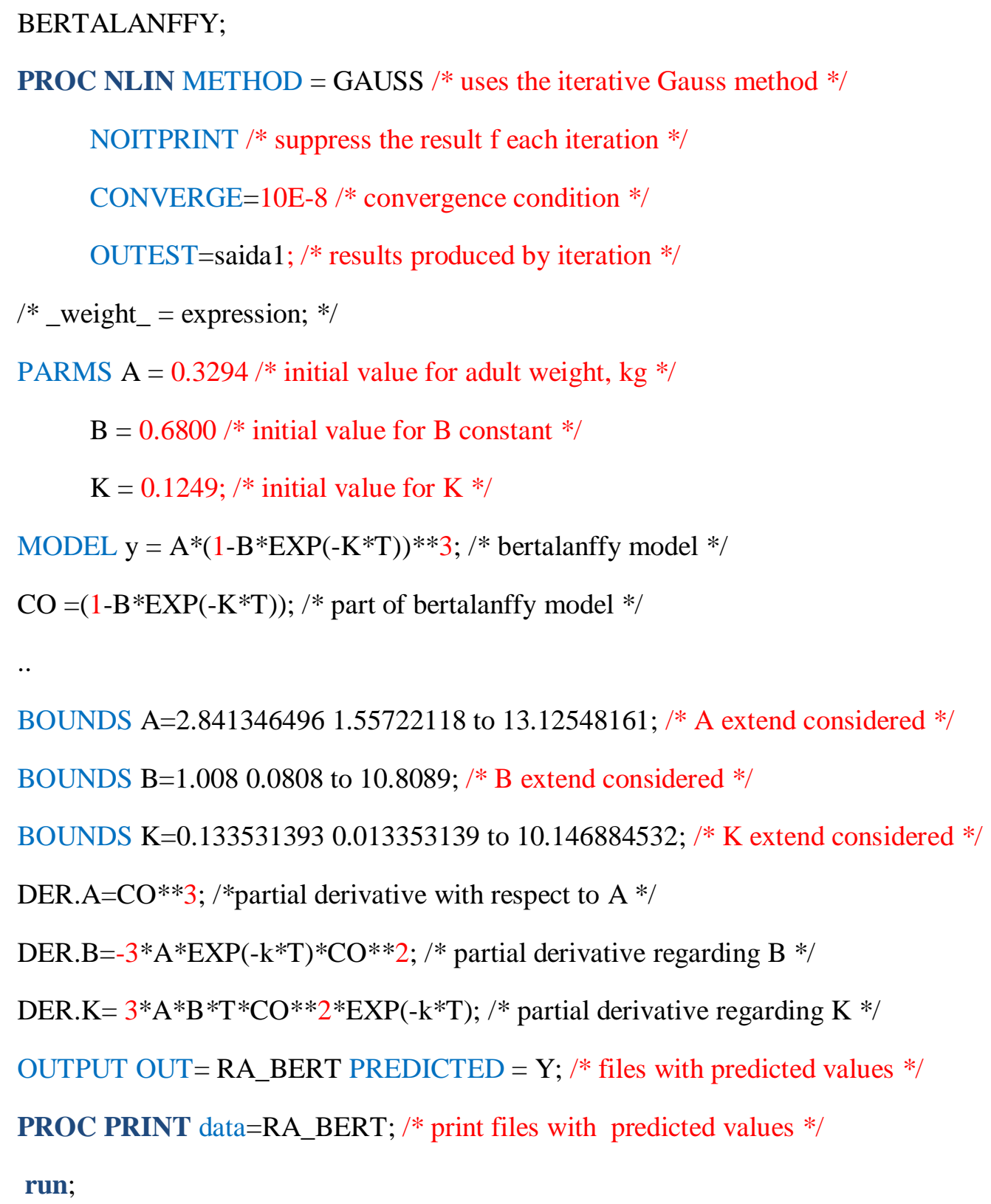




\section{RESULTS AND DISCUSSION}

The parameters estimates for each type of animal growth used to predict growth, in mass $(\mathrm{kg})$, of Nile tilapia raised in net cages are shown in Table 1.

TABLE 1. Estimated values for the parameters A, B and $\mathrm{k}$ for all models analyzed.

\begin{tabular}{lcccc}
\cline { 2 - 5 } Model & \multicolumn{4}{c}{ Parameter } \\
\cline { 2 - 5 } & $\mathrm{A}$ & $\mathrm{B}$ & $\mathrm{K}$ & $\mathrm{M}$ \\
\hline Brody & 13.4853 & 0.9812 & 0.0001 & - \\
Bertalanffy & 4.122 & 0.9257 & 0.0037 & - \\
Logistic & 1.521 & 43.7867 & 0.0183 & - \\
Gompertz & 2.383 & 5.3516 & 0.0075 & - \\
Richards & 0.9728 & 0.4483 & 0.0086 & 4.8917 \\
\hline
\end{tabular}

Figure 1 shows the behavior of the mass accumulation of tilapia, for Y-observed (observed mass) and Y-estimated (estimated weight) to 270 days of rearing.

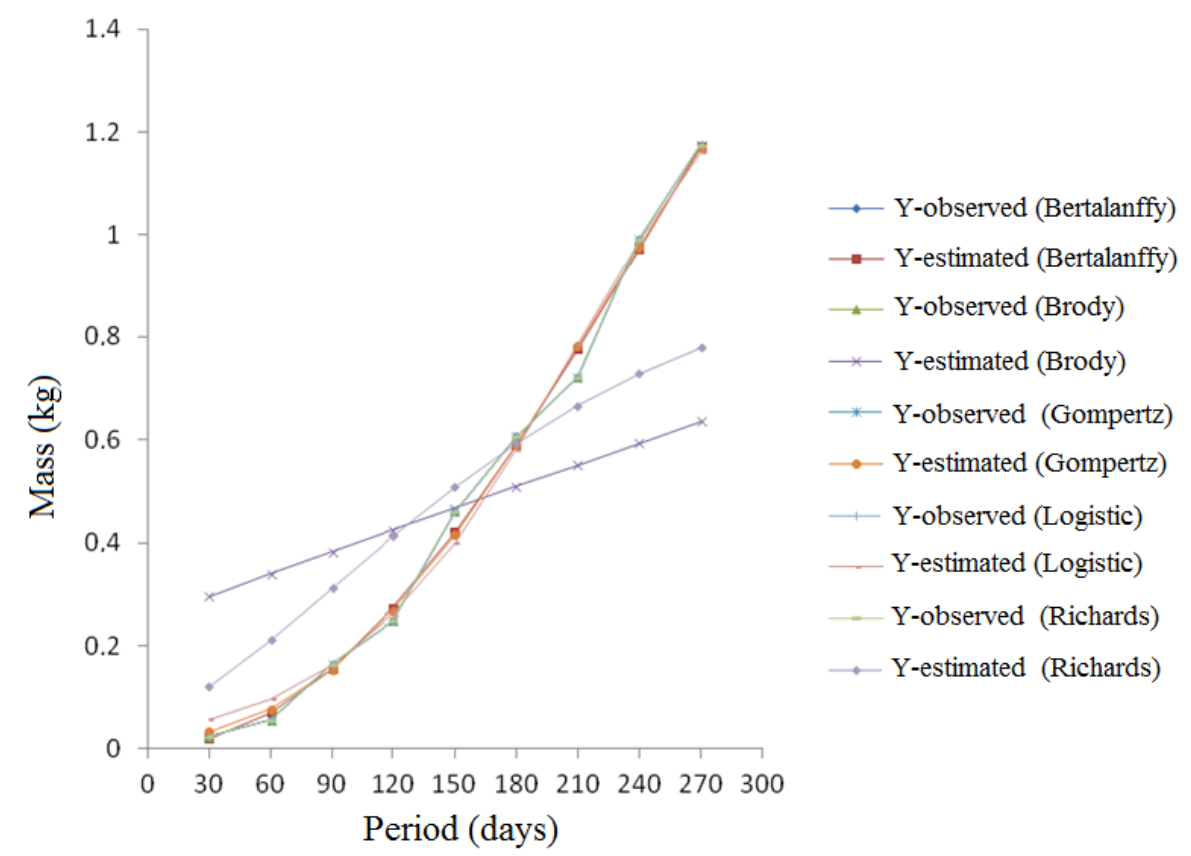

FIGURE 1. Growth curves observed and estimated according to the models, for 270 days of rearing: Bertalanffy, Brody, Logistic, Gompertz and Richards.

Below are shown the set of adjusted equations from Brody, Bertalanffy, Gompertz, Logistic and Richards models, according to the equations: Eq.6, Eq.7, Eq.8, Eq.9 e Eq.10, respectively:

$$
\begin{aligned}
& Y=13.4853\left(1-0.9812 e^{-0.000108 t}\right) ; \\
& Y=4.122\left(1-0.9257 e^{-0.00369 t}\right)^{3} ; \\
& Y=2.383 e^{-5.3516 e^{-0.00747 t}} ; \\
& Y=1.5210\left(1+43.7867 e^{-0.0183 t}\right)^{-1} ; \\
& Y=0.9728\left(1-0.4483 e^{-0.00856 t}\right)^{4.8917} ;
\end{aligned}
$$


In the evaluation of this species, the tilapia, studies of growth curves by adjusting the weight prediction equations based on the animal age has been important. The requirements for achieving success in animal production are becoming increasingly stringent (CORDEIRO et al., 2012).

In the present study, Brody and Richards models overestimated values of initial mass and underestimated the final values for the 270 days of rearing (Figure 1). FREITAS (2007) modeling the goats growth through nonlinear models, concluded that, Brody, Logistic and Bertalanffy were adequate to estimate the goats growth, in all ages, being the only exception, the birth weight, because the three models overestimated it in the magnitude of $10 \%$.

Taking the results of the logistic model, in particular, it is observed that is one of the tested models that best adjust the observed weights, as obtained by MCMANUS et al. (2003): the adult weight estimated was also lower than those other tested curves (Brody, Richards) for bergamasca sheep in the region of Brasilia.

The parameter A (Table 1) represents the estimate of the asymptotic weight, which is interpreted as adult weight. The estimates of the parameter $\mathrm{A}$, in $\mathrm{kg}$, of tilapia was higher for Brody (13.4853), Bertalanffy (4.1220), and Gompertz (2,383), followed by Logistics model (1.521) and Richards (0.9728). This result differs from that found by MANRIQUE (2012), when modeling the Aracá bandeira growth (Ptherophyllum scalare), where the Logistic model had the lowest asymptotic weight (A) $13.98 \mathrm{~g}$ and the highest value was obtained by Bertalanffy, with $66.62 \mathrm{~g}$.

The average weight of tilapia searched by the consumer market is around $600 \mathrm{~g} / 850 \mathrm{~g}$ to $1 \mathrm{~kg}$, in other words, the total tilapia fattening cycle occurs, approximately, in 180 days in net cages (NOGUEIRA, 2007 ). In this context, the fish in the present study could be marketed from 183, 247, 181, 184, 183 days for Bertalanffy, Brody, Gompertz, Logistic and Richards models, respectively, when they reach the minimum weight marketing: $600 \mathrm{~g}$. And to limit mass of $1 \mathrm{~kg}$, would require 244, 546, 244 and 243 days for Bertalanfy, Brody, Gompertz and Logistic models.

There was an inability to predict the time required to the estimative time (days) required to the tilapias to achieve $1 \mathrm{~kg}$ of body weight on Richards model: the value of A (Table 1) is less than the desired estimate (Y-estimated). So far, this model is not recommended for calculations of Yestimated for the cultivation of tilapia in net cages in the Sub middle of São Francisco river, when the desired weight is greater than or equal to $972 \mathrm{~g}$. It is reiterated here that, this result is due to the lack of data convergence, which will be further explored.

The parameter $\mathrm{k}$ (Table 1) represents the rate of maturity of the animal and indicates the growth velocity to achieve asymptotic weight. According to MALHADO et al. (2009a), the lower k value, slower the animal will approach its asymptotic weight, in other words, lower is the growth velocity of the animal in order to reach its adult weight.

The largest value of $\mathrm{k}$ in this study was obtained by the Logistic model (0.0183), followed by Richards (0.00856), Gompertz (0.00747), Bertalanffy (0.00369) and Brody (0.00011). A similar result was obtained by MANRIQUE (2012), when modeled the Aracá bandeira growth (Ptherophyllum scalare) with Bertalanffy, Logistic, Gompertz models, where it was found that the Logistic model showed the highest growth velocity (parameter k equal to 0.025 ), being followed by Richards (0.02), Gompertz (0.0088) and Bertalanffy (0.0034).

In Bertalanffy model, as $\mathrm{k}$ is equal to 0.00369 and its asymptotic value is $4.1220 \mathrm{~kg}$, would be necessary, theoretically (since intrinsic and extrinsic variables are influencing the fish growth) just over 4 years and 7 months of rearing to obtain tilapia of, at least $4 \mathrm{Kg}$. If, hypothetically, the values of A were kept and changed the value of $\mathrm{k}$ to 0.0369 , it would take 169 days to get tilapia with $4 \mathrm{~kg}$. For Gompertz model, $\mathrm{k}$ is equal to 0.00924 , asymptotic value of $1.8499 \mathrm{~kg}$, and theoretically would take 570 days for the tilapias obtain $1.8 \mathrm{~kg}$ of mass. 
Serving only to promote adjustment of the data to the models, the parameter B, will not be analyzed in this study. In Table 2, are shown the criteria used for comparison of the mathematical models reviews.

TABLE 2. Coefficient of determination, Convergence and Sum of deviations according to the models studied.

\begin{tabular}{lccc}
\hline Model & Convergence & $\mathrm{R}^{2}$ & $\mathrm{SQD}$ \\
\hline Brody & No & 0.4688 & 0.722 \\
Bertalanffy & Yes* $^{*}$ & 0.9983 & 0.00614 \\
Logístico & Yes* $^{*}$ & 0.9967 & 0.0117 \\
Gompertz & Yes* $^{*}$ & 0.998 & 0.00708 \\
Richards & No & 0.9116 & 0.3147 \\
\hline
\end{tabular}

*Converged by Gauss method.

Based on convergence, only 3 models converged by Gauss method. None of the models converged by other iterative methods: Newton, Gradient and Marquardt. The convergence of a model ensures that its estimated parameters better adjusts to the data analyzed, in other words, the sum of residual squares (SRS) is the minimum possible.

The lack of convergence of Brody model, in this study, resembles that occurred in the ESPINGOLAN et al. (2009), when they tried to adjust this model to analyze the weight of Hereford steers. As for Richards, the non-convergence of data is consistent with those described by KARKACH (2006), in their review of the way and growth (mass), states that the adjustment of Richards model may fail in convergence, in some non specific occasions, which does not happen so obviously for other models.

COSTA et al. (2009) who studied the tilapia growth, discarded Bertalanffy and Brody models because they did not adjust into any lineage. Such variations in the choice of the best model are consequences of several factors, in addition to the statistical aspect, but also the need to assess it from the point of biological view of the parameter estimates produced by them (MENDES et al., 2008).

Based on the coefficient of determination (Table 2), there is similarity between the Bertalanffy, Gompertz and Logistic models, because they have higher $\mathrm{R}^{2}$ values of 0.99. FREITAS \& COSTA (1983) and RODRIGUES et al. (1992) studying the different functions (Bertalanffy, Gompertz and Logistic) to estimate pigs growth rates, from birth to slaughter, concluded that the models had good data adjusts, with high values of $\mathrm{R}^{2}$.

Similar results were obtained in several studies that aimed to model the weight growth in relation to the length of animal species for commercial purposes: cattle and goats (FREITAS, 2007), sheep (GUEDES et al., 2004), shrimp (SILVA et al., 2007) and rabbit (FREITAS, 2007), for the Bertalanffy model, as presented $\mathrm{R}^{2}$ greater than 0.99 .

Other studies argue that the Gompertz model best describes the growth of the species analyzed, outweighing other existing models, because of the high value of the coefficient of determination: frogs (RODRIGUES, 2007), cattle (MENDES et al, 2009), horses (MCMANUS et al. 2010). In addition to the Gompertz model obtain high value of $\mathrm{R}^{2}$ for Gompertz, the other discarded models shown value of $\mathrm{R}^{2}$ less than 0.30 .

And for the Logistic model, are examples of good adjusts and high $\mathrm{R}^{2}$ (greater than 0.99 ) to the following studies: fish (VANDER et al, 2012.), plants (LYRA et al., 2008), cattle (MALHADO et al., 2009b), among others, all with the goal of modeling the growth of the species analyzed with respect to $t$.

In the comparison between Brody, Logistic, Richards, Bertalanffy and Gompertz models, in a study of beef cattle growth, pointed to the Gompertz model as the most appropriate for estimating 
the growth of Nellore cattle (PAZ et al,. 2004). However, PEROTTO et al. (1992) suggests the Richards model as the most appropriate for estimating the growth of Zebu females.

The Bertalanffy model provided a suitable curve for Santa Ines sheep specie, showing the moment of growth stabilization (FREITAS, 2005). In another study of Santa Inês sheep originating from experimental herd in Paraíba, the Gompertz model showed higher average setting, and therefore is indicated to describe the average growth curve (SARMENTO et al., 2006). In the same study, observed that Santa Inês sheep, males and females born from single or double births, showed divergent pattern growth, indicating the need of different curves to describe their growth.

As the sum of squared deviations (Table 2), the Bertalanffy model and Gompertz are similar, because SRS is equal to 0.00614 and 0.00708 , respectively. The logistic model has SRS value larger than the other models: 0.0117. Figure 2 represents tilapia mass growth analyzed, for Yestimated (estimated weight), of Bertalanffy and Gompertz models, for theorists 1000 days of rearing.

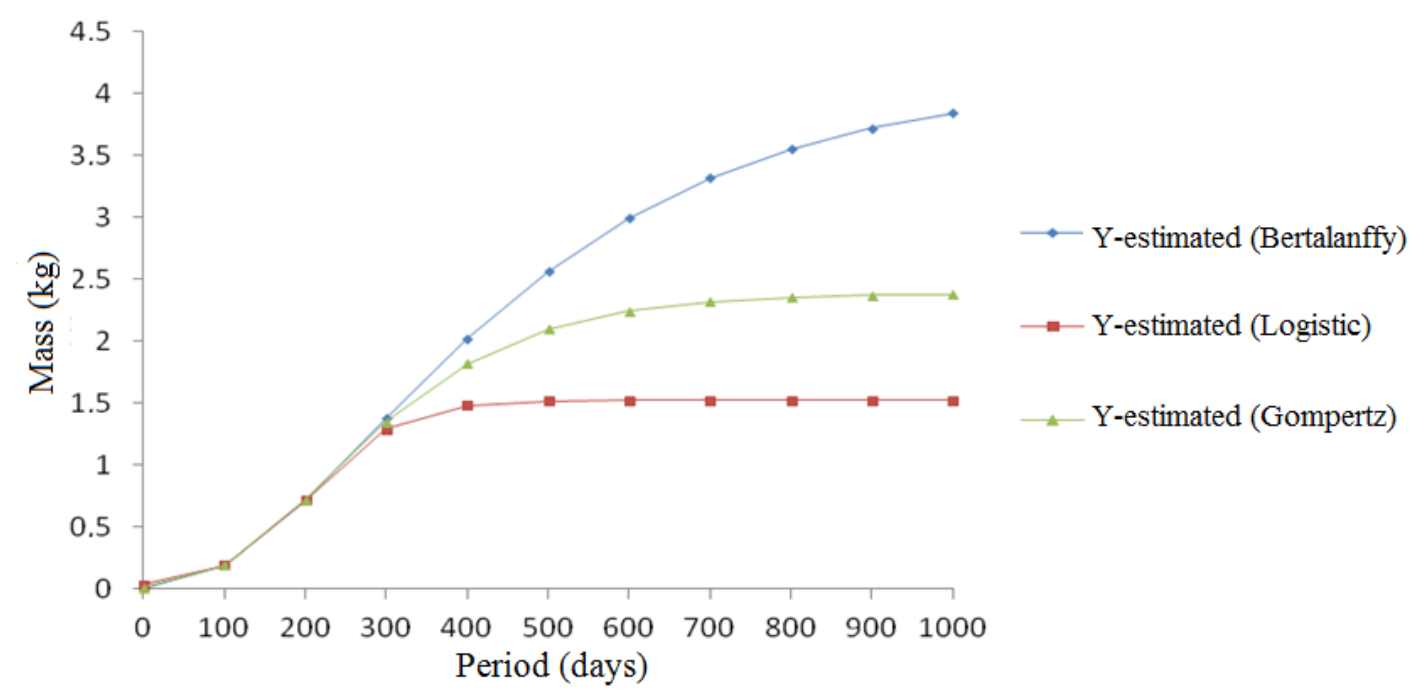

FIGURE 2. Growth curves estimated according to the models: Bertalanffy, Logistics and Gompertz to 1000 days of rearing.

Based on Figure 2, it is observed that even by passing theoretical 1000 days of rearing, the Bertalanffy model did not stabilized, unlike the Gompertz and Logistic models. Although there are reports in the literature of tilapia with up to $5 \mathrm{~kg}$ mass (FAO, 2012), this value is far from the national average, which is $600 \mathrm{~g}$ to $1 \mathrm{~kg}$ (NOGUEIRA, 2007). Growth stages have different biological significance, being their analysis recommended separately (PASSOS et al., 2012), as the case of tilapia mass above the average. In such cases, should take into account the growing point can be considered almost constant, in other words, when the curve is sufficiently close to the asymptote, indicating no significant difference (MISCHAN et al., 2011).

Bertalanffy, Gompertz and Logistic models are only indicated for tilapia rearing with crops of up to 270 days for net cages. Furthermore, it would be necessary data of rearing higher than 270 days to validate the models for projections beyond the period of this study, which is not available in this study.

\section{CONCLUSION}

Good adjusts are obtained with the Bertalanffy, Gompertz and Logistic models, up to 270 days of rearing. These models are recommended for monitoring growth, in weight, of Nile tilapia reared in net cages in the Sub middle of São Francisco river.

The adjusted models in this study can be used by growers of Nile tilapia, allowing to obtain accurate information about mass growing of animals, besides allowing information for making 
future decisions regarding sales/management, for animals of the same species with the same environmental conditions (rearing conditions be similar and that the rearing happens in the Sub middle of São Francisco river).

\section{REFERENCES}

BAIO, F. H. R., RODRIGUES, A. D., SANTOS, G. S., SILVA, S. P. Modelagem matemática para seleção de conjuntos mecanizados agrícolas pelo menor custo operacional. Engenharia Agrícola, Jaboticabal, v.33, n.2, apr. 2013. Disponível em: <http://www.scielo.br/scielo.php?script=sci_artte xt\&pid=S0100-69162013000200018\&lng=en\&nrm=iso>. Acesso em: 2 nov 2013.

BARD, J. "Comparison of gradient methods for the solution of the nonlinear parameter estimation problem," SIAM Journal of Numerical Analysis, Philadelphia, v.7, p. 157-186, 1970.

BARD, J. Nonlinear Parameter Estimation, New York: Academic Press, Inc. 1974.

BERTALANFFY, L. von. Quantitative laws in metabolism and growth. Quarterly Review of Biology, Chicago, v.32, p.217-230, 1957.

BRODY, S. Bioenergetics and growth. New York: Reinhold, 1945. 1023 p.

CODEVASF - Companhia de Desenvolvimento dos VAles do São Francisco e do Parnaíba. Manual de criação de peixes em tanques-rede. Brasília: Codevasf, 2010. 69 p.

CORDEIRO, A. F. S., NÄÄS, I. A., OLIVEIRA, S. R. M., VIOLARO, F. A., ANDRÉIA C. M. Efficiency of distinct data mining algorithms for classifying stress level in piglets from their vocalization. Engenharia. Agrícola, Jaboticabal, v.32, n.2, apr. 2012. Disponível em: $<$ http://www.scielo.br/scielo.php?script=sci_arttext\&pid=S0100-69162012000200001\&lng=en\&nr m=iso>. Acesso em: 3 dez. 2013.

COSTA, A.C.; NETO, R.V.R.; FREITAS, R.V.F.; FREATO, T.A.; LAGO, A.A.; SANTOS, V.B. Avaliação do crescimento de tilápias de diferentes linhagens através de modelos não-lineares. Archivos de Zootecnia, Cordova, 58, Supl. 1, p. 561-564, 2009.

ESPINGOLAN, R.; ALBUQUERQUE, L.G.; BALDI, F.; BOLIGON, A.A. Comparação de modelos não-lineares utilizando pesos de novilhos da raça Hereford. In: CONGRESSO DE INICIAÇÃO CIENTÍFICA DA UNESP, 21., 2009, São José do Rio Preto. Anais...

FAO - Organização das Nações Unidas para Alimentação e Agricultura. Cultured aquatic species information programme Oreochromis niloticus. Programa de información de especies acuáticas. Roma: Departamento de Pesca y Acuicultura de la FAO, 2012. Disponível em: <http://www.fao.org/fishery/culturedspecies/Oreochromis_niloticus/es> Acesso em: 29 nov. 2013.

FREITAS, A. R. Estimativas de curvas de crescimento na produção animal. São Carlos: Embrapa Pecuária Sudeste, 2007. (Documentos 68).

FREITAS, A.R.; COSTA, C.N. Ajustamento de modelos não lineares a dados de crescimento de suínos. Pesquisa Agropecuária Brasileira, Brasília, v.18, n.10, p.1147-54, out., 1983.

FREITAS, A. R. Curvas de crescimento na produção animal. Revista Brasileira de Zootecnia, Viçosa, MG, v.34, n. 4, p.786-795, 2005.

GUEDES, M.H.P.; MUNIZ, J.A.; PEREZ, J.R.O.; SILVA, F.F.; AQUINO, L.H.; SANTOS, L.C. Estudo das curvas de crescimento de cordeiro das raças Santa Inês e Bergamácia considerando heterogeneidade de variâncias. Ciência e Agrotecnologia, Lavras, v. 28, n. 2, p. 381-388. 2004.

HARTLEY, H.O. The Modified Gauss-Newton Method for the Fitting of Non-Linear Regression Functions by Least Squares. Technometrics, 3, 269-280. 1961. 
JENNRICH, R.I. Asymptotic properties of nonlinear least squares estimators. Annals of Mathematical Statistics, v. 40, p. 633-643, 1969.

JENNRICH, R.I.; MOORE, R.H. Maximum likelihood estimation by means of nonlinear least squares. Alexandria: American Statistical Association, 1975. p. 57-65.

KARKACH, A.S. Trajectories and models of individual growth. Demographic Research,

v. 15, n.12, p.347-400, 2006.

KUBITZA, F. Tilápias na bola de cristal. Panorama da Aquicultura, Rio de Janeiro, v.17, n 99. jan/fev. 2007.

LAIRD, A.K. Dynamics of relative growth. Growth, Bar Harbor, v.29, p.249-263,1965.

LYRA, G.B.; SOUZA, J.L.; LYRA, G.B.; TEODORO, I.; FILHO, G.M. Modelo de crescimento logístico e exponencial para o milho BR 106, em três épocas de plantio. Revista Brasileira de Milho e Sorgo, Sete Lagoas,. v. 7, n.3, p. 211-230, 2008.

MACLEOD, A.J. A generalization of Newton-Raphson. International Journal Mathematics Education Scence. Technology, v.15, n.1, p.117-120. 1984.

MALHADO, C.H.M.; CARNEIRO, P.L.S.; MELLO, P.R.A.M. et al. Growth curves in Dorper sheep crossed with the local Brazilian breeds, Morada Nova, Rabo Largo, and Santa Inês. Small Ruminant Research, Amsterdam, v.84, p.16-21, 2009a.

MALHADO C.H.M.; RAMOS, A.A.; CARNEIRO, P.L.S.; AZEVEDO, D.M.M.R.; MELO P.R.A.R.; PEREIRA, D.G.; SOUZA, J.L.; MARTINS, F.R. Modelos não lineares utilizados para descrever o crescimento de bovinos da raça Nelore no estado da Bahia: 1. Efeito ambiental. Revista Brasileira de Saúde e Produção Animal, Salvador, v. 10, p. 821-829. 2009 b.

MANRIQUE, C.H.E. Modelos não lineares, alometria e dinâmica das macromoléculas para analisar o crescimento do acará bandeira (Ptherophyllum scalare). 2012. 93f. Dissertação (Mestrado) - Universidade Estadual Paulista, Centro de Aquicultura, Jaboticabal.

MARQUARDT, D. W., An algoritmo for least - squares estimation of nonlinear paramenter. SIAM Journal Applied Mathematicas, Philadelphia, v.11, p. 431 - 441, 1963.

MCMANUS, C.; LOUVANDINI, H.; CAMPOS, V. Curvas de crescimento não-lineares para peso e altura em quatro grupos genéticos de cavalos. Revista Ciência Animal Brasileira, Goiânia, v.11, n.1, p.80-89, 2010.

MCMANUS, C; EVANGELISTA, C; FERNANDES, L. A. C.; MIRANDA, R. M.; et al. Curvas de Crescimento de Ovinos Bergamácia Criados no Distrito Federal, Revista Brasileira de Zootecnia, Viçosa, MG, v.32, n.5, p.1207-1212, 2003.

MENDES, P. N.; MUNIZ, J.A.; SILVA, F.F.E.; MAZZINI, A.R.A ; SILVA, N.A.M. . Análise da curva de Crescimento Difásica de Femêas Hereford por Meio da Função Não Linear de Gompertz. Revista de Ciência Animal Brasileira, Goiânia, v. 10, p. 454-461, 2009.

MENDES, P.N.; MUNIZI, J.A ET AL.; FONSECA, F.; MAZZINI, A.R.A. Modelo logístico difásico no estudo do crescimento de fêmeas da raça Hereford. Ciência Rural, Santa Maria, v.38, n.7, p.1984-1990, 2008.

BRASIL. Ministério da Pesca e Aquicultura. Produção pesqueira e aquícola - Estatística 2008 e 2009/ 2010. Brasília, 2010. p. 17.

MISCHAN, M.M.; PINHO, S.Z.; CARVALHO, L. R. Determination of a point sufficiently close to the asymptote in nonlinear growth functions. Scientra Agricola, Piracicaba, v. 68, n. 1, feb. 2011. Disponível em: <http://www.scielo.br/scielo.php?script=sci_arttext\&pid=S010390162011000100016\&lng=en\&nrm=iso>. Acesso em: 13 nov 2013. 
NELDER, J.A. The fitting of a generalization of the logistic curve. Biometrics, Washington, v.17, p.89-110, 1961.

NOGUEIRA, A. Criação de tilapias em tanques-rede. São Paulo: SEBRAE, 2007. Disponível em: <http://www.biblioteca.sebrae.com.br/bds/BDS.nsf/7227D4D9D30AB6CC832573A9006DF4BC/\$ File/NT0003737A.pdf > . Acesso em: 20 nov. 2013.

PASSOS, J. R. S.; PINHO, S. Z.; CARVALHO, L. R.; MISCHAN, M. M. Critical points in logistic growth curves and treatment comparisons. Scientia Agricola, Piracicaba, v.69, n.5, p. 308-312, 2012.

PAZ, C.C.P; PACKER I.U.; FREITAS A.R. et al. 2004. Ajuste de modelos não-lineares em estudos de associação entre polimorfismos genéticos e crescimento em bovino de corte. Revista Brasileira de Zootecnia, Viçosa, MG, v.33, n.6, p.1416-1425.

PEROTTO, D.; CUE, R.I.; LEE, A.J. Comparison of nonlinear functions for describing the growth curve of three genotypes of dairy cattle. Canadian Journal of Animal Science, Ottawa, v.72, p.773$782,1992$.

RATKOWSKY, D. Handbook of nonlinear regression models. New York: Marcel Dekker, 1990.

RICHARDS, F.J. A flexible growth function for empirical use. Journal of Experimental Botany, Oxford, v.10, p.290-300, 1959.

RODRIGUES, M. L.; LIMA, S.L.; MOURA, O. M.; AGOSTINHO, C.A.; SILVA, J.H.V.; CRUZ, G.R.B.; CAMPOS, V.M.; CASALI, A.P.; MENDES, R.B.; ALBUQUERQUE, A. G. Curva de Crescimento em rã-touro na fase de recria. Archivos de Zootecnia, Córdoba, v. 56, n. 214, p. 125136. 2007.

RODRIGUES, P.B.; MUNIZ, J.A.; PEREIRA, F.A. Estudo comparativo de curvas de crescimento em suínos. Ciência e Prática, v.16, n.1, p.151-157, 1992. SAS: SAS 9.1 for windows - Portable version (Free). Cary: SAS, 2003.

SARMENTO, J. L. R. et al. Estudo da curva de crescimento de ovinos Santa Inês. Revista Brasileira de Zootecnia, Viçosa, MG, v.35, n.2, p. 435-442, 2006.

SIANGAS, L.E; POUILLY, M.; VALLEJOS, A.; PÉREZ, T.; REJAS, D. Effect of water quality on growth of four fish species in the Iténez basin (Upper Madera, Amazon). Environmental Biology of Fishes, v. 95, n. 3, p. 371 - 381, nov. 2012.

SILVA, M. C. N.; FRÉDOU, F. L.; ROSA FILHO, J. S. 2007. Estudo do crescimento do camarão Macrobrachium Amazonicum (Heller, 1862) da Ilha de Combú, Belém, Estado Do Pará. Amazônia: Ciência \& Desenvolvimento, Belém, v. 2, n. 4, p. 85-104, 2007.

TEXEIRA, M.C.; VILLARROEL, A.B.; PEREIRA, E.S.; OLIVEIRA, S.M.P.; ALBUQUERQUE, I.A.; MIZUBUTI, I.Y.; Curva de crescimento de cordeiros oriundos de três sistemas de produção na Região Nordeste do Brasil. Semina: Ciências Agrárias, Londrina, v. 33, n. 5, p. 2011-2018, set./out. 2012.

VANDER, B.S; FREITAS, R.T.F; SILVA, F.F; FREATO, T.A. Avaliação de curvas de crescimento morfométrico de linhagens de tilápia do nilo (Oreochromis niloticus). Ciência. Agrotecnica., Lavras, v. 31, n. 5, p. 1486-1492, set./out. 2007.

VANDER, B.S.; YOSHIHARA, E.; MARECO, E.A.; FREITAS, R.T.F.; FREITAS, R.T.F. Muscle growth of two Nile tilapia (Oreochromis niloticus) strains. Journal of Agricultural Science and Technology, Wellington, v. 2, p. 1195-1202, 2012.

WU, Y. Estimation of gas saturation using P to S converted waves. Calgary: Annual Meeting SEG, 2000. 